\section{Langley Memorial Prize, 1962}

The Langley Memorial Prize was founded by the friends of the late Dr. W. H. Langley, principal medical officer, Southern Nigeria, to commemorate his work and the services he rendered both to Nigeria and to those who came under his care and skill.

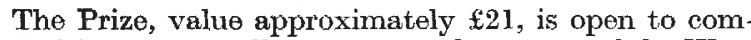
petition among officers, past and present, of the West African Medical Departments; it is awarded period. ically for the best paper on one of the following subjects: (a) tropical medicine or surgery; $(b)$ tropical hygiene and sanitation; $(c)$ tropical entomology and parasitology. Special consideration is given to original work. Joint applications are not accopted. No officer who has already boen awarded the Prize is eligible to re-entor. Entries, which can consist of either published or unpublished work, should be sent to the Dean, London Sehool of Hygieno and Tropical Medicine, Keppel Street, Gower Street, London, W.C.1, not Inter than October 1.

\section{University News :}

Birmingham

THE following appointments are announced; Prof. L. E. Davis, professor of industrial engineering in the University of California, to be Joseph Lucas visiting professor for the session 1962-63; Research Fellows : Dr. W. N. Cottingham (mathematical physics), Dr. G. P. McCauley (mathematical physics), Mr. J. A. R. Griffith (physics), Mr. H. C. Wilkie (pure mathematics); Lecturer, Dr. B. Musgrave (physics).

Bristol

Tre following appointments are announced: Dr. D. Russell Davis, reader in medical psychology and director of the Medical Psychology Laboratory in the University of Cambridge, to be professor of mental health and head of the Department of Mental Health; Readerships, Dr. D. T. Donovan (palæontology), Dr. W. D. Ollis (organic chemistry), Dr. B. F. Folkes (botany), Dr. P. H. Fowler (physics); Senior Lectureships, Dr. M. H. Rogers (mathematics, as director of the Computer Unit), Mr. T, V. Lawson (aeronautical engineering), Mr. R. C. Seymour (chemistry), Mr. S. R. Wragg (agricultural economics); Research Associate, Dr. J. G. Baker (physics); Lecturer, Dr. P. J. Bentloy (pharmacology).

Cambridge

THE following elcetions to followships at Churchill College havo been announced: Title A, Dr. A. Howie, demonstrator-elect in the Department of Physics and College lecturer in physics; Dr. R. C. Campbell of Gonville and Caius College, University lecturer in agricultural statistics and College lecturer in mathematics for natural sciences; Title B (Junior Research Fellowships), B. W. Cherry of Trinity College, for research in metallurgy (the Goldsmiths' Followship in Metallurgy); M. A. A. Clyne of Trinity College, for research in physical chemistry; A. E. Dorey of Jesus Collego, for research in zoology; Title $C, \mathrm{D}$. G. Kendall, professor-elect of mathematical statistics.

\section{Oxford}

DR. M. D. Gwynne, Junior Resoarch Fellow at Balliol College, has been elected to the Mount Endow= ment Senior Research Fellowship in tropical cology (with effect from September 29) at that College.

Weizmann Institute of Scieince

The following appointments have been announced: Dr. J. H. Jaffe, to be professor in the Department of
Infra-Red Spectroscopy; Associate Professorships, Dr. Yehuda Eisenberg (nuclear physics), Dr. David Danon (polymers), Dr. Carl A. Levinson (nuclear physics), Dr, Uriel Littauer (biochemistry); Senior Scientists, Dr. N. Haran-Gera (experimental biology), Dr. N. Trainin (experimental biology), Dr. A. Nir (isotopes), Dr. A. Patchornik (biophysics), Dr. A. Frankel (applied mathematics), Dr. A. Aharoni (electronics).

\section{Announcements}

MR. D. G. RYAN has been appointed Ruthorford Scholar by the Council of the Royal Society for three years beginning in October. Mr. Ryan will continue his work, in the University of Birmingham, on pionpion resonances in the deuteron-deuteron interactions.

Prof. A. S. Parkes (Physiological Laboratory, Cambridge) has been elected chairman of the Scientific Publications Council in succession to Prof. G. W. Harris (Institute of Psychiatry, London). Mr. A. V.S. de Reuck (Ciba Foundation, London) has been elected honorary secretary, and the other members of the Steering Committee are Mr. A. L. Bacharach, Dr. R. K. Callow, Prof. G. W. Harris and Dr, D. Richter.

THE sixteenth International Horticultural Congress, sponsored by the Government of Belgium, will be held in Brussels during August 31 -September 8. Furthor information can be obtained from the Secretary, Sixteenth Intornational Horticultural Congress, 233 Coupure Links, Ghent.

The Mullard Research Laboratories will be holding open days during July 4-6. During these days, cach of the five divisions will be showing aspects of the research programmes in physics, electronics and allied fields that are being undertaken at the Laboratorios. Further information can be obtained from Mullard, Ltd., Mullard House, Torrington Place, London, W.C.1.

AN international symposium on "Environmental Control of Plant Growth", organized under the auspices of the International Union of Biological Sciencos, will be held at the Academy of Scionce, Canberra, during August 25-31. Further information can be obtainod from Dr. L. T. Evans, Division of Plant Industry, Commonwealth Scientific and Industrial Research Organization, P.O. Box 109 City, Canberra, A.C.T.

As informal discussion, sponsored by the Faraday Society, on "Forces in Colloidal Systems", is to be held in the Department of Chemistry, University of Nottingham, during September 20-21. There will be two half-day sessions, which will include papers on: (a) stability of dispersions in aquoous and non-aqueous systems; (b) micellization. Further information can be obtained from Dr. G. D. Parfitt, Department of Chemistry, The University, University Park, Nottingham.

Erratum. In the article entitled "Isotope Effects in the Infra-red Spectrum of $1-{ }^{13} \mathrm{C}-$ Propene-1" by Dr. W. O. George, which appeared on p. 672 of the May 19 issue of Nature, the units on the abscissa of Fig. 1 should read 940,920, 900, 880 and 860 , and not $1,040,1,020,1,000,980$ and 960 as printed. 